\title{
EARLY WEANING FROM BREASTFEEDING FROM MOTHERS' PERSPECTIVE: A DIALOGICAL APPROACH ${ }^{1}$
}

\author{
Carolina Viviani Clapis Prado², Marcia Regina Cangiani Fabbro³, Graziani Izidoro Ferreira ${ }^{4}$
}

\footnotetext{
${ }^{1}$ This paper was taken from the thesis - Breastfeeding and early weaning: transforming and excluding aspects, presented to the Programa de Pós-Graduação em Enfermagem, Universidade Federal de São Carlos (UFSCar), in 2012.

${ }^{2}$ M.Sc. in Nursing. Nurse, Family Health Program, Itirapina. Itirapina, São Paulo, Brazil. E-mail: carolvclapis@yahoo.com.br

${ }^{3}$ Ph.D. in Education. Professor, Departamento de Enfermagem, UFSCar. São Carlos, São Paulo, Brazil. E-mail: mfabbbro@gmail.com

${ }^{4}$ M. Sc. in Nursing. UFSCar. São Carlos, São Paulo, Brazil. E-mail: gra.izidoro@gmail.com
}

\begin{abstract}
The complex issue of early weaning from breastfeeding suggests making the mother the main character in this phenomenon. Beyond listening to that character, the Critical Communicative Method proposes to equate scientific and popular knowledge. The goal was to identify the transforming aspects and obstacles to early weaning with 12 mothers who weaned early. The study was developed in the interior of São Paulo, in 2010 and 2011, using communicative reporting, communicative discussion group and a questionnaire. Results show young mothers, primipara, married, who finished secondary or technical school and did not have a paid job. The breastfeeding revealed emotions like bonding with the baby, but also feelings of failure and frustration. The equalitarian dialogue revealed that obstacles remain rooted in culture, which need to be discussed with the mothers, and not only judged and condemned, looking for strategies to overcome early weaning through intersubjectivity.
\end{abstract}

DESCRIPTORS: Early weaning. Breastfeeding. Postpartum period.

\section{DESMAME PRECOCE NA PERSPECTIVA DE PUÉRPERAS: UMA ABORDAGEM DIALÓGICA}

RESUMO: A complexidade do desmame precoce sugere tornar a mãe personagem principal deste fenômeno. Mais do que ouvir essa personagem, a Metodologia Comunicativa Crítica propõe colocar em igualdade o conhecimento científico e o popular, por meio do diálogo igualitário. Este estudo tem objetivo de identificar aspectos transformadores e obstáculos para o desmame precoce com 12 mães que desmamaram precocemente. Foi realizado no interior de São Paulo, no período de 2010 e 2011, utilizando o relato comunicativo, grupo de discussão comunicativo e questionário. Os resultados mostram mães jovens, primíparas, casadas, ensino médio/técnico completo e não trabalhavam fora de casa. A amamentação revelou emoções como vínculo com bebê, mas também sentimentos de derrota e frustração. O diálogo igualitário permitiu apreender que ainda existem obstáculos enraizados na cultura que precisam ser dialogados com as mães, e não somente julgados e condenados, buscando, por meio da intersubjetividade, estratégias de superação do desmame precoce.

DESCRITORES: Desmame precoce. Aleitamento materno. Período pós-parto.

\section{LACTANCIA MATERNA Y DESTETE PRECOZ DEL PUNTO DE VISTA DE LAS MADRES: UN ENFOQUE DIALÓGICO}

RESUMEN: La complejidad del destete precoz sugiere hacer de la madre el personaje principal de este fenómeno. Más que escucharlas, la Metodología Comunicativa Crítica, propone poner en igualdad, el conocimiento científico y el popular, por medio del diálogo igualitario. El objetivo es identificar los aspectos de las transformaciones y los obstáculos para la lactancia materna. Resultados de datos recolectados en 2010 e 2011 en el interior de São Paulo, a través de grupo de discusión, muestran madres jóvenes, primíparas, casadas, de educación secundaria y no trabajadoras. La lactancia materna reveló emociones como vínculo con el bebé, pero también sentimientos de derrota y frustración. El diálogo igualitario reveló que aún existen obstáculos arraigados en la cultura que deben ser dialogados con las madres, y no sólo juzgados y condenados, buscando, por medio de la intersubjetividad, estrategias de superación del destete precoz.

DESCRIPTORES: Deteste precoz. Lactancia materna. Período postparto. 


\section{INTRODUCTION}

The World Health Organization (WHO) recommends exclusive breastfeeding (EB) as an important strategy to reduce childhood mortality. It is defined as the (exclusive) offering of breast milk for the infant's first six months of life, after which foods and other fluids should be associated to breast milk. ${ }^{1}$

The advantages of exclusive breastfeeding until the age of six months are more effective than breastfeeding until the age of three or four months, followed by mixed lactation. These advantages include reducing the risk of gastrointestinal infection in the infant, greater maternal weight loss after birth and increased length of return period to menstruation. ${ }^{2}$ Studies reveal that most children hospitalized with diarrhea received formula milk, proving the protective effect of exclusive breastfeeding. ${ }^{3}$

Breastfeeding is socially constructed as a biological, natural, innate act, characteristic of mother and child, but the breastfeeding act comes with a cultural context that can be related to a social obligation, resulting from a rational choice and motivated by advantages and benefits for mother and baby, which can lead to early weaning for countless reasons. ${ }^{4}$ This is defined as the interruption of breastfeeding before the infant has completed six months of life, independently of whether the mother makes this decision or not and the reason for this interruption. ${ }^{5}$

Early weaning is a reality in Brazil, as only $41 \%$ of infants under six months of age in Brazilian capitals and the Federal District were on EB. The median length of exclusive breastfeeding is 54.1 days (1.8 months). The North presented the highest prevalence $(45.9 \%)$, followed by the Central-West $(45.0 \%)$, South $(43.9 \%)$ and Southeast $(39.4 \%)$, while the Northeast shows the worst situation (37.0\%), according to the most recent national research published. ${ }^{6}$

Concerning the complexity of the early weaning phenomenon, countless factors can influence it, such as biological, historical-cultural, economic social and mental, showing a process loaded with ideologies and determinants that result from unconscious and concrete living conditions. ${ }^{7}$

In this sense, the health professionals' difficulties to manage breastfeeding issues may represent another obstacle to maintain exclusive breastfeeding. According to a study, health professionals face difficulties to solve practical issues related to orientations for the mothers, directly influencing the exclusive breastfeeding rates. ${ }^{8}$
Managing breastfeeding difficulties requires a set of technical and relational skills that depart from good interaction with the postpartum women. The nurses should learn to develop sensitive listening and be capable of observing the breastfeeding women's difficulties in order to promote and support breastfeeding, helping them to overcome the initial difficulties in the breastfeeding process. ${ }^{9}$ This evidences that the communication process established between health professional and client favors the development of the skills and competences needed for people to find, understand, assess and use health-related information. ${ }^{10}$

Therefore, other approaches had to be used that do not only privilege the postpartum women's voice, but advance to construct overcoming strategies together with them. Therefore, this study intended to use a research method that has been consolidated abroad, through the Special Research Center in Theories and Practices to Overcome Inequalities (CREA) at the University of Barcelona/ Spain and is called the Critical Communicative Method (CCM) ${ }^{11}$ The CCM rests on Habermas' ${ }^{\prime 12}$ work on Communicative Action and Paulo Freire's concept of Dialogicity. ${ }^{13}$

The research question was: how can we dialogically understand early weaning based on the interaction with women who experienced it? The objective was to identify the elements that represented obstacles and transforming aspects of the early weaning and breastfeeding experience.

\section{METHOD}

The CCM departs from the following premises: universality of language and action (any person's ability to communicate and interact, which are universal attributes of all people); people are transforming social agents (all people are agents who transform their contexts); communicative rationality (as opposed to instrumental rationality); common sense (the subjective sense that depends on the life experience, gained in the cultural context itself); no interpretive hierarchy (the validity of the interpretive premises is equal among the people investigated and the researcher, who does not grant his/her role as scientific interpreter); same epistemological level (everyone appoints his/her interpretations and experiences, looking for consensual arguments) and dialogic knowledge (built based on communication and dialogue among people and groups). ${ }^{11}$

The intent was to dialogically understand the meaning of the weaning for the women. The 
information produced in dialogical spaces offers new knowledge through the identification of transforming aspects, that is, aspects that contribute to overcome the barriers that impede or make it difficult to incorporate a person or group into a practical or social benefit. The obstacles, on the other hand, are the barriers a person or group experiences to participate in a social practice or benefit.

The study was developed in a city in the interior of the state of São Paulo, involving 12 mothers who lived in different neighborhoods. These were recruited from Family Health services in the city where the researcher worked as a nurse, which made it easier to locate and contact them, which was done personally or by telephone. The only inclusion criterion was the occurrence of early weaning before the age of six months and that weaning should have happened three months earlier at most, due to the possible forgetting of information. The data collection tools were: communicative report (a type of distinguished individual interview), communicative discussion group (a type of distinguished group interview) and a questionnaire (to characterize the participants). The data were collected between 2010 and 2011. The data collection was closed of when data saturation was verified. The project was submitted to the Ethics Committee for Research involving Human Beings (CAAE: 0472.0.000.135-10/ Opinion 269/2010).

The research involved three phases:

$1^{\text {st }}$ phase: collective construction of communicative report script. The definitive script was elaborated together with women from the community who dialogically shared their knowledge with the researcher. The encounters happened during the woman's health consultations, gymnastics group and at the waiting room of the health services. The information was written down in a field diary and then included in the form of questions in the definitive script, used in the next phase. These women participated only in this initial construction phase of the scripts, that is, they did not take part in the subsequent phases. The critical communicative method is based on the premise that each person, independently of his/her educational, cultural or socioeconomic condition, possesses cultural intelligence, that is, (s)he can analyze the experiences and propose ways to revert the situation. ${ }^{14}$ In this sense, the collective construction of the data collection tools is an important phase in the method, as the intention is to overcome the methodological gap between the investigators and the research subjects, producing knowledge through the creation of an intersubjective dialogue; therefore, any woman who has experienced breastfeeding could suggest themes to help and construct the script. ${ }^{11}$ At the same time, the questionnaire was elaborated to characterize the investigate women's profile.

$2^{\text {nd }}$ phase: elaboration of communicative report. In this distinguished interview, a dialogue takes place between the researcher and participant to interpret and reflect on the study participant's daily life. In this dialogue, interaction takes place between the researcher, who exposes her scientific knowledge on the research theme and confronts it with the participant's experience and knowledge. Key questions for the participant are elaborated to develop the dialogue, according to questions identified earlier. The interviews were held at the mothers' homes, recorded and fully transcribed. The women were identified using the initial of their first name, so as to preserve their identity. After the interviews, the researcher returned to the mothers for a second meeting, aimed at reaching a consensus on the results obtained, broadening and deepening aspects they found necessary to validate the collected data. ${ }^{11}$

$3^{\text {rd }}$ phase: communicative discussion group. Through this technique, the individual subjectivity can be confronted with the group subjectivity, establishing contact among different people, experiences, viewpoints, among others. ${ }^{11}$ The group was held departing from a script, constructed based on the analysis of the interviews, and was audio recorded, revealing new contributions and clarifications of themes that had been discussed in the interviews.

The analysis process was based on the premises of the CCM and followed the steps of information transcription, coding, description, interpretation of this information, results and conclusions. ${ }^{11}$ The basic analysis level was used, which comprises the ranking of the elements that represented obstacles and that were identified as transformations in the aspects of EB and early weaning. ${ }^{11}$ Thus, the number of elements refers to the quantity listed as obstacles and/or transformations, highlighted in the statements; and the number of mentions refers to the number of statements the participants presented on a given element. For the sake of this paper, elements were used that were mentioned four times or more to compose the themes, so as to prioritize the most mentioned elements. ${ }^{15}$

The analysis steps were: full transcription of the interview and data analysis of the questionnaire on the characteristics of the participants' profile, using Microsoft Office Excel 2007; exhaustive reading of the data; identification of the excerpts in the moth- 
ers' statements about the factors that represented obstacles and transformations. Set-up of initial tables for each mother; allocations of contributions from the second encounter; allocation and contribution of communicative discussion group; elaboration of final table with pre-themes and construction of themes and subthemes in the final matrix.

The category discussed in this article was "the process of breastfeeding and early weaning", with the subthemes: meanings of breastfeeding and early weaning and knowledge on the process of breastfeeding and early weaning. This category relates to the feelings, experiences and position of the mothers towards these processes.

\section{RESULTS AND DISCUSSION}

The participants' profile consists of young mothers aged up to 29 years, totaling $84 \%$; most of them had a stable marital relationship, being $42 \%$ married; $59 \%$ had finished secondary/technical education; the majority (75\%) were primipara and did not have a paid job at the time of the research.

\section{Meanings of breastfeeding and early weaning}

The early weaning experience was not something the mothers wanted, as proven when they mention feeling sad about the weaning. This fact was identified as a transforming aspect, in that it was not planned: [...] I felt sad, I wanted to breastfeed $\operatorname{him}[\ldots](\mathrm{J})$.

These negative feelings towards the weaning also appeared in another study in which the women reported sadness, impotence and frustration regarding the process. ${ }^{16}$ Women experienced similar feelings when breastfeeding in public. In a study developed in England involving 63 mothers, it was concluded that they experience judgments and condemnations during interactions with the health professionals and the community, causing feelings of failure, inadequacy and isolation. ${ }^{17}$

The mothers' report evidenced that breastfeeding was a very desired practice, symbolizing the transmission of kindness, affection, approximation, trust, safety for the child and increased bonding between mother and child. Experiencing breastfeeding and understanding that this process is essential for the mother and child bond transforms this into a striking experience in the woman's life and makes it possible, although in the future, to overcome some obstacles inherent in the practice of breastfeeding and not weaning early: [...] it was very pleasant for me, because it didn't hurt a bit [...]. Like, the baby stays closer to us, gets calmer, it makes him and us feel safe [...] (K).

In a study developed in New Haven, Connecticut, United States to compare the functional magnetic resonance of breastfeeding and nonbreastfeeding mothers, it was concluded that there were links between breastfeeding and greater maternal response to child stimuli in regions of the brain involved in the mother-infant link and empathy in the postpartum phase. ${ }^{18}$ In Brazil, in a study involving mothers from Bahia, it was also concluded that successful breastfeeding qualifies the mother's performance, with a social and family meaning in the woman's life. ${ }^{19}$

In addition, the mothers identified that the weaning increased the family's spending, due to the purchase of bottles and milk formulas. Reflecting on this during the dialogue with the researcher was a transforming element, as it was during the experience of weaning that the financial aspect was revealed and also permitted the association between breastfeeding and reducing the family spending: [...] it's much easier for you, when he cries, you take out your breast and feed him... so after you wean him everything increases, it's a remedy [...] (P). The cost of infant milk formulas is a relevant aspects and the women in this study identified that exclusive breastfeeding has no cost when compared to formula feeding. ${ }^{20}$

Also, the hope of experiencing successful breastfeeding with a next child was identified. These aspects are transforming, as hoping to be able to achieve this is a form of encouragement and indirect prevention of future weaning: [...] but I really wanted him to have the opportunity to breastfeed, but I didn't manage... I think, like, I'll try, if I have another child I'd do the same thing [...] (SIR).

In this sense, the intention or desire to breastfeed can serve as a precursor of adherence to this practice. In a study involving 2400 pregnant women from Bangladesh, it was concluded that correct knowledge on breastfeeding, positive attitudes and high levels of self-efficacy and trust of the mothers concerning breastfeeding influenced the intention to exclusively breastfeed. ${ }^{21}$ Despite earlier unsatisfactory breastfeeding experiences, however, the mothers in another study wanted and intended to experience it differently with their second child, idealizing a successful breastfeeding experience. ${ }^{22}$

Having support from family and friends to breastfeed was an aspect most mothers mentioned, and was identified as a transforming element, as breastfeeding cannot be a solitary process, but should engage all stakeholders: family, friends and 
society: [...] he used to do everything, took the baby for me to breastfeed, because the first week I couldn't get up, he participated in that part, he [husband] was on holiday [...] (K).

Presenting similar results, a study reveals that the family helped the mothers to serve as protagonists in breastfeeding, organizing the husbands' co-participation, who provided for daily care while the mothers were breastfeeding. Breastfeeding is linked to the family's breastfeeding experience. From a phenomenological perspective, breastfeeding is a sociocultural practice, that is, a process of interaction with the family and daily social life. ${ }^{19}$ In another study, the father and grandmother were identified as the main references of support for the breastfeeding woman, evidencing the need to gather family members in health care activities. ${ }^{23}$

Although weaning was not something the mothers wanted or had planned, it caused feelings of defeat, failure, inability, representing an obstacle, as this negative and self-blaming look could influence further breastfeeding experiences: [...] I'm no use not even to give milk, what the hell am I going to be useful for in this world... I feel frustrated, it's bad [...] (D).

The feeling of inability the early weaning causes is very common, which can provoke a feeling of failed motherhood. ${ }^{24}$ The interaction between the researcher and the women allowed them to notice that the guilt only causes feelings of uselessness, which are not positive. These feelings need to be overcome and hope needs to focus on a new pregnancy and on the strength to want to do things differently.

\section{Knowledge on the process of breastfeeding and early weaning}

Although early weaning happened to these mother, all of them understood the minimum period recommended for EB (six months), which was identified as a transforming element: [...] I think that up to the age of six months, that would be ideal for the child to breastfeed [...] (P).

Nevertheless, possessing the knowledge was not sufficient to avoid early weaning, a fact revealed in other studies that identified that the percentage of mothers who demonstrate knowledge on EB $(63.8 \%)$ is high, but still insufficient and involving contradictory information. ${ }^{25}$ In a study undertaken in Malaysia, the knowledge and beliefs on breastfeeding were assessed, involving 213 breastfeeding mothers. It was concluded that, to guarantee a successful breastfeeding practice, besides knowledge and attitude, issues involving culture and traditions need to be addressed in the counseling provided, and better support is needed. ${ }^{26}$

In this sense, trained health professionals are important actors in this context. A study developed in Sweden revealed that the professionals are central to support the breastfeeding women and their families, associating the training of midwifes and nurses with the reduction in the number of children who were receiving breast milk substitutes in the first week of life, thus postponing the introduction of milk formulas after the hospital discharge. ${ }^{27}$ The breastfeeding women revealed that knowledge on exclusive breastfeeding departed from what they had learned from the health professionals, in whom they revealed a high level of confidence. ${ }^{20}$

Some mothers were familiar with the physiology of breast milk production and ejection. These were considered transforming elements, as they permit advising the mothers to follow routines that favor EB, such as breastfeeding on demand, not controlling the length of the feeding session, among others: [...] he was not sucking, then it finished, right, because the child needs to suck for more milk to come out, to produce more milk [...] (S).

Knowing the physiology of breast milk production and ejection is extremely important to maintain the breast milk and, in most cases, this knowledge derives from the mother's education, which takes place before giving birth and while breastfeeding. Nevertheless, studies appoint that the knowledge remains limited and may reveal that the woman needs to be accompanied. ${ }^{28-29}$

The mothers are familiar with and experienced the consequences of using milk formulas, mentioning the difficulties for the babies to adapt to them. Intestinal constipation was the difficulty they mentioned most. These elements were considered transforming aspects, as knowing about the risks of milk formulas make the mothers rethink their conducts and assess risks and benefits: [...] I started with $N A N$, then I stopped, because I saw he dried out [...] (S).

A study that associated the type of feeding with the consumption of dietary fiber and the occurrence of constipation in infants revealed that, in the first semester, formula-fed infants demonstrated 4.5 times more chance of constipation than predominantly breastfed children. ${ }^{30}$

A study undertaken at a hospital in Canada, involving 17 mothers, revealed that, for the mother who describe their breastfeeding as successful, it is understood as physiologically natural and as something that should be learned. Failed experiences 
reveal that the health professionals interpret the breastfeeding as not "functioning" and the discourse changes to the formula as a means to achieve excellent child health. ${ }^{31}$

Most of the interviewees mentioned the advantages of EB for child health and knew about the protective effect of breast milk. These are considered transforming elements, that is, knowing the benefits of breastfeeding turns the act into a commitment of the mother to the present and future health of her child: [...] breastfeeding is a... how can I say it, it's ideal milk. The milk that most avoids disease, allergy, you see $[. .].(\mathrm{N})$.

Differently from the present study findings, in another research, it was concluded that approximately $30 \%$ of the interviewees did not know about the importance of the colostrum, but other authors evidence that, even for mothers who know about the properties of breast milk and some of its advantages, this was insufficient to maintain and continue the breastfeeding practice, demonstrating that knowledge is necessary but not sufficient to incorporate healthy habits, as mentioned earlier. ${ }^{28,32-33}$

Practicing exclusive breastfeeding does not only benefit the child who is breastfed, but also the mother who breastfeeds, mainly in the immediate postpartum. Most of the mothers did not mention this knowledge, who reported that they did not know about the advantages of breastfeeding for maternal health. This fact was considered an obstacle, as not knowing the advantages makes these mothers breastfeed only for their child's sake, forgetting themselves. This facilitates the weaning and the woman loses the opportunity to make use of the benefits for their own health. In addition, it can make the mother feel guilty for not putting in practice her social role as a nursing mother, which society expects. This was reflected in the interaction with the women: [...] Ah, I never went to the lecture, I don't know it well, I know about the advantages for them, mine to tell you the truth I don't know [...] (TH).

A study involving mothers of children under six months of age identified that the benefits the mothers mentioned were related to the prevention of illnesses in the baby, teething and reduced family spending on food. They did not mention any benefit for the mother, in accordance with the present study. ${ }^{34}$

The need for the presence of the nipple to breastfeed was a noteworthy element in most interviewed mothers' statements. Besides relating it with hereditary aspects, the presence of the nipple was a conditio sine qua non for correct latching on and, thus, for successful breastfeeding. The mothers tried different forms to revert the non-protrusion of the nipple, using some non-recommended strategies for this purpose.

The dialogue resulting from the communicative discussion group revealed that the difficulties deriving from flat or malformed nipples cannot be denied, but this impregnated belief in the women, in combination with the health professional's lack of support, gives feedback to the women's exclusive responsibility for failed breastfeeding: [...] I had a bit of a nipple, then after she was born it disappeared, I think the breast got swollen and, then, without my nipple, that made it difficult too [...] (N). The perception that only protruding nipple permit correct latching on was also evidenced in another study in which, of all mothers with flat nipples, $25 \%$ indicated thinking that the baby does not latch on easily, while only $8.8 \%$ of the mothers with normal nipples $(81 \%)$ had this complaint. ${ }^{35}$

In the mothers' statements, some myths related to breastfeeding were identified, such as: breast milk is weak, does not sustain, causes colic in the baby and high bodily temperatures and maternal agitation interfere in breast milk. Through the dialogue between scientific and popular knowledge, the consensus could be reached that these myths are considered obstacles to breastfeeding, as they favor inappropriate conducts that can lead to early weaning: [...] until I got to my job, then I had to wait for her to calm down a bit, because it was very hot, I had to wait for the milk to calm down [...] (K).

The mothers used these myths as justifications for the weaning and only $4.3 \%$ of the mothers assumed having weaned their infant without a reason. ${ }^{36}$ In one study, $47 \%$ of the postpartum women mentioned the myth that the breast milk is weak, believing that, through exclusive breastfeeding, the baby would gain little weight. ${ }^{37}$ Another study pictures that the pregnant women and mothers' doubts and myths on breastfeeding originate in the lack of information or inappropriate orientation, which negatively influences the breastfeeding practice. ${ }^{37-38}$

When we open a communication channel detached from hierarchies and prescriptions, the mothers rethink their perspective on breastfeeding and weaning, overcome their fears and try to cling to the hope of getting a new chance to breastfeed their children. This communication needs to take place at a level of equality with the mothers, based on a dialogue that respects the interpretations of the reality in function of the validity of the arguments, of the researcher as well as the subject, instead of 
the power and/or status rankings. Nevertheless, the need for further research is clear, especially using CCM, which permits reaching other levels of transformation through intersubjectivity.

Considering breastfeeding from the perspective of reproductive rights, the women, as owners of their body, are entitled to the right to carry, give birth to and breastfeed their child. The health professionals are responsible for welcoming them, understanding their way of life and respecting their opinion, in order to support them in their breastfeeding decisions. ${ }^{39}$

\section{CONCLUSION}

The complexity of the factors intertwined with early weaning reveals the need not to homogenize the phenomena in order to value each woman's viewpoint in its particularities. Through the proposed methods, the premises could be put in practice by privileging reflection and equalitarian dialogue with the mothers who participated in the research through the experience of early weaning and breastfeeding.

Through this research, the breastfeeding process could be experienced based on the view and experience of the mothers who weaned early and who, even in adverse situations, understood the meaning of breastfeeding and the knowledge detached from this process. Early weaning was not something planned and the women revealed the hope of experiencing breastfeeding successfully in future experiences, which is transforming for them and all other women who will experience this process.

Early weaning did not picture the idea that breastfeeding was not experienced intensely, considering that, despite the difficulties faced, the mothers were able to let go of facilitating aspects of breastfeeding, such as practicality; the bond of kindness and pleasure with the child; the offer of health to the child and the importance of support from the family and health professionals.

There are obstacles the mothers who weaned early need to overcome. Most of these are rooted in the dominant culture of the biological determinism of breastfeeding and need to be dialogued with the parents and society, instead of just judged and condemned. The need for salient nipples; the conformism with pain during breastfeeding; companies' non-compliance with labor laws in favor of breastfeeding and the belief in breast milk myths were some of these obstacles that need to be reconsidered and deepened in other studies.

Experiencing early weaning means that the mothers, family and society relive the breastfeeding process maturely; it means overcoming the prejudices and stigmas surrounding these experiences, which are social processes. The health professionals also need to reconsider their conducts towards early weaning, so as to no longer see it as the end point but as the starting point for new learning experiences.

The search for the transforming elements and announcers of capacities to overcome the breastfeeding difficulties and avoid early weaning, as well as the revelation of the obstacles and overcoming strategies, show the great potential of the method used. Overcoming early weaning remains an action for the future and this study was intended to discuss this theme by means of a method that can bring other perspectives.

\section{REFERENCES}

1. American Academy of Pediatrics. Breastfeeding and the use of human milk. Pediatrics. 2012;129(3):827-41.

2. Kramer MS, Kakuma R. Optimal duration of exclusive breastfeeding, The Cochrane Library, n. 4, 2009.

3. Santos FS, Santos FCS, Santos LH, Leite AM, Mello DF. Breastfeeding and protection against diarrhea: an integrative review of literature. Einstein (São Paulo). 2015; 13(3):435-40.

4. Frota MA, Costa LF, Soares SD, Filho OAS, Albuquerque AM, Casimiro CF. Fatores que interferem no aleitamento materno. Rev Rene. 2009 Jul-Set; 10(3):61-7.

5. Parizotto J, Zorzi NT. Breast-feeding: factors leading to precocious weaning in Passo Fundo, RS. O mundo da Saúde: São Paulo. 2008; 32(4):466-74.

6. Venancio SI, Escuder MML, Saldiva SRDM, Giugliani ERJ. Breastfeeding practice in the Brazilian capital cities and the Federal District: current status and advances. J Pediatr. 2010; 86(4):317-24.

7. Sampaio MA, Falbo AR, Camarotti MC, Vasconcelos MGL, Echeverria A, Lima G,. Psicodinâmica interativa mãe-criança e desmame. Psicol: Teor Pesq. 2010; 26(4):613-21.

8. Souza NL, Araujo ACPF, Costas ICC. The meanings that postpartum women assign to gestational hypertension and premature birth. Rev Esc Enferm USP. 2011; 45(6):1285-92.

9. Baptista SS, Alves VH, Souza RMP, Rodrigues DP, Cruz AFN, Branco MBLR. Manejo clínico da amamentação: atuação do enfermeiro na unidade de terapia intensiva neonatal. Rev Enferm UFSM. 2015; Jan-Mar; 5(1):23-31. 
10. Flecha A, Ruiz L, Vrecer N. La alfabetizaciónen salud y el empoderamiento de las comunidades. Diálogo igualitário entre los profesionales de la salud y la comunidad. Scripta Nova. 2013 [cited 2016 Mar 1]; 17(427):. Available from: http://www.ub.edu/ geocrit/sn/sn-427/sn-427-5.htm

11. Gomez J, Latorre A, Sanchez M, Flecha R. Metodologia comunicativa crítica. Barcelona (ES): El Roure Editorial; 2006.

12. Habermas J. Teoria do agir comunicativo: Racionalidade da ação e racionalização social. São Paulo (SP): Editora WMF Martins Fontes; 2012.

13. Freire, P. Pedagogia do oprimido. 43 ed. Rio de Janeiro: Paz e Terra; 2005.

14. Oliver E, Botton L, Soler M, Merril B. Cultural intelligence to overcome educational exclusion. Qualitative Inquiry. 2011; 17(3):267-76.

15. Gabassa V. Comunidades de aprendizagem: a construção da dialogicidade na sala de aula [tese]. São Carlos (SP): Universidade Federal de São Carlos; 2009.

16. Quirino LS, Oliveira JD, Figueiredo MFER, Quirino GS. Significado da experiência de não amamentar relacionado às intercorrências mamárias. Cogitare Enferm. 2011 Out-Dez; 16(4):628-33.

17. Thomson G, Burton KE, Flacking R. Shame if you do - shame if you don't: women's experiences of infant feeding. Matern Child Nutr. 2015 Jan; 11(1):33-46.

18. Kim P, Feldman R, Mayes LC, Eicher V, Thompson N, Leckman JF, Swain JE.. Breastfeeding, brain activation to own infant cry, and maternal sensitivity. J Child Psychol Psychiatry. 2011 Aug; 52(8):907-15.

19. Demétrio F, Silva MCM, Santos SMC, Assis NMO. Meanings attributed to breastfeeding in the first two years of life: a study with women from two municipalities in the Recôncavo Baiano region of Bahia, Brazil. Rev Nutr. 2013; 26(1):5-16.

20. Thet MM, Khaing EE, Smith ND, Sudhinaraset M, Oo S, Aung T. Barriers to exclusive breastfeeding in the Ayeyarwaddy Region in Myanmar: Qualitative findings from mothers, grandmothers, and husbands. Appetite. 2015; 96(2016):62-9.

21. Thomas JS, Yu EA, Tirmizi N, Owais A, Das SK, Rahman S, et al. Maternal knowledge, attitudes and self-efficacy in relation to intention to exclusively breastfeed among pregnant women in rural Bangladesh. Matern Child Health J. 2015 Jan; 19(1):4957.

22. Esteves AM, Sonego JC, Vivian AG, Lopes RCS, Piccinni CA. A gestação do segundo filho: sentimento e expectativas da mãe. Psico. 2013; 44(4):542-51.

23. Sousa AM, Fracolli LA, Zoboli ELCP. Práticas familiares relacionadas à manutenção da amamentação: revisão da literatura e metassíntese. Rev Panam Salud Publica. 2013; 34(2):127-34.

24. Polido CG, Mello DF, Parada CMGL, Carvalhesma MABL, Tonete VLPl. Vivências maternas asociadas ao aleitamento materno exclusivo mais duradouro: um estudo etnográfico. Acta Paul Enferm. 2011; 24(5):624-30.

25. Silva PS, Moraes MS. Caracterização de parturientes adolescentes e de seus conhecimentos sobre amamentação. Arq Ciênc Saúde. 2011; 18(1):28-35.

26. Ishak S, Adzan NAM, Quan LK, Shafie MH, Rani NA, Ramil KG. Knowledge and beliefs about breastfeeding are not determinants for successful breastfeeding. Breastfeed Med. 2014; 9(6):308-12.

27. Ekstrom A, Kylberg E, Nissen E. A process-oriented breastfeeding training program for healthcare professionals to promote breastfeeding: an intervention study. Breastfeeding Med. 2012; 7(2):85-92.

28. Rocha NB, Garbin AJI, Garbin CAS, Moimaz SAS. $\mathrm{O}$ ato de amamentar: um estudo qualitativo. Physis. 2010; 20(4):1293-305.

29. Galiano JMM, Rodriguez MD. El inicio precoz de la lactancia materna se ve favorecido por la realización de la educación maternal. Rev Assoc Med Bras. 2013; 59(3):254-57.

30. Aguirre ANC, Vitolo MR, Puccini RF, Moraes MB. Constipação em lactentes: influência do tipo de aleitamento e da ingestão de fibra alimentar. J Pediatr. 2002; 78(3):202-8.

31. Braimoh J, Davies L. When 'breast' is no longer 'best': Post-partum constructions of infant-feeding in the hospital. Soc Sci Med. 2014 Dec; 123:82-9.

32. Garg R, Deepti SS, Padda A, Singh T. Breastfeeding knowledge and practices among rural women of punjab, india: a community-based study. Breastfeeding Med. 2010; 5(6):303-7.

33. Campos AAO, Ribeiro RCL, Santana LFR, Castro FAF, Reis RS, Oliveira CA, et al. Práticas de aleitamento materno: lacuna entre o conhecimento e a incorporação do saber. Rev Med Minas Gerais. 2011; 21(2):161-7.

34. Frota MA, Mamede ALS, Vieira LJES, Albuquerque $\mathrm{CM}$, Martins $\mathrm{MCl}$. Cultural practices about breastfeeding among families enrolled in a Family Health Program. Rev Esc Enferm USP. 2009; 43(4):895-901.

35. Benedett, Silva IA, Ferraz L, Oliveira P, Fragoso E, Ourique J. Pain and discomfort in the practice of breastfeeding. Cogitare Enferm. 2014; 19(1):136-40.

36. Simões IAR, Rennó G, Salomon ASC, Martins $\mathrm{MCM}$, Sá RAD. Influência dos mitos e das crenças nas nutrizes quanto amamentação em uma Cidade do Vale do Paraíba. Rev Ciências Saúde [online]. 2015 [cited 2016 Mar 01]; 5(3). Available from: http:/ / 186.225.220.234:8484/rcsfmit/ojs-2.3.33/ index.php/rcsfmit_zero/article/view/385

37. Melo MCP, Marques HVN, Valois HR, Coelho IMS, Souza JA, Silva JCR. Vivências do projeto mitos e tabus do aleitamento materno: vamos desfazer esse nó? RESVASF. 2013; 2(2):11-9.

38. Barbosa JAG, Santos FPC, Silva PMC. Fatores associados à baixa adesão ao aleitamento materno 
exclusivo e ao desmame precoce. Rev Tecer. 2013; 6(11):154-65.

39. Monteiro JCS, Gomes FA, Nakano AMS. Amamentação e o seio feminino: uma análise sob a ótica da sexualidade e dos direitos reprodutivos. Texto Contexto Enferm. 2006; 15(1):146-50. 